\title{
INTERRELATIONSHIPS BETWEEN LYING AND DIFFERENTIAL TYPES OF REFLECTION IN ACQUISITIVE CRIMINALS-RECIDIVISTS
}

У статmі представлено теоретичний аналіз наукових праць у царині психологіі щодо особливостей рефрлексії та прояву брехливості. Проаналізовано зміст феномена рефлексії й різних проявів брехливості. Рефрлексія розглядається як здатність усвідомлювати й адекватно оцінювати себе та оточуючих. Брехливість аналізується як індивідуально-психологічна особливість корисливих злочинців-рецидивістів, які в кримінальній діяльності неодноразово вдавалися до брехні з метою отримання матеріальної винагороди й задоволення власних корисливих мотивів. Відповідно до мети та завдань роботи, здійснено емпіричне дослідження взаємозв'язків брехливості з дисеренційними типами рефрлексії в корисливих злочинців-рецидивістів.

Детально розкриваються результати емпіричного дослідження френомена брехливості й рефрлексивних проявів особистості в корисливих злочинців-рецидивістів. Вибірку становили 53 засуджені, які були позбавлені волі за злочини, передбачені Карним кодексом України (шахрайство, вимагання, розбій, грабіж, крадіжка). Утворено дві групи досліджуваних, до яких корисливі злочиниі-рецидивісти включені на грунті результатів кластерного аналізу за принципом «ближніх сусідів». Використано опитувальник «Диореренційний тип ресрлексії» Д. Леонтьєва $і$ «Структурно-фрункціональний опитувальник брехливості» І. Церковної. Установлено, що перша група корисливих злочинців переважає другу групу досліджуваних за всіма диферениійними типами ресрлексії. Визначено, що дисререниійні типи ресрлексії виявляють відмінності в структурі взаємозв'язків зі структурно-фрункціональними складниками брехливості в обох досліджуваних групах, що свідчить про специфріку внеску рефрлексії у функціонування брехливості в цих респондентів.

Ключові слова: рефрлексія, брехливість, особистість, корисливі злочинці, рецидивісти, дисреренційні типи рефрлексії.
The article presents a theoretical analysis of scientific works in the field of psychology on the features of reflection and the manifestation of deceit. The content of the phenomenon of reflection and various aspects of the manifestations of lying are analyzed. Reflection is seen as the ability to be aware of and adequately evaluate himself/herself and others. Lying is analyzed as an individual-psychological feature of asquisitive recidivist criminals, who in their criminal activity have repeatedly resorted to lying in order to obtain material reward and satisfy their own asquisitive motives.

In accordance with the purpose and objectives of the work, an empirical study of the relationship between lying and differential types of reflection in asquisitive recidivists has been performed. The results of an empirical study of the phenomenon of lying and reflexive manifestations of personality in asquisitive recidivist criminals are revealed in detail. The sample consisted of 53 convicts who were imprisoned for crimes under the Criminal Code of Ukraine (fraud, extortion, robbery, theft).Two groups of subjects were formed, to which asquisitive criminals-recidivists were included on the basis of the results of cluster analysis on the principle of "nearest neighbour". We used the questionnaire "Differential type of reflection" by D. Leontiev and "Structural and functional questionnaire of deceit" by I. Tserkovna. It is established that the first group of asquisitive criminals outperforms the second group of subjects in all differential types of reflection. It is determined that the differential types of reflection reveal differences in the structure of relationships with the structural and functional components of deceit in both groups, which indicates the specific contribution of reflection in the functioning of deceit in these respondents.

Key words: reflection, lying, personality, asquisitive criminals, recidivists, differential types of reflection.
Харківський національний університет внутрішніх справ
Постановка проблеми. Психологічна наука пропонує безліч досліджень рефлексії, котрі мають власне трактування цього поняття й розкривають зміст їі предмета. В умовах сьогодення актуальними є питання рефлексивних можливостей людини, здатність особистості усвідомлювати та адекватно оцінювати себе й оточуючих. Ця особистісна риса потрібна для того, щоб ефективно діяти в постійно мінливому середовищі та мати змогу працювати над власними помилками. Прагнення людини виглядати краще в очах інших людей, ніж $€$ насправді, провокує їі вдаватися до брехні (обману). Усе більше в психології наростає інтерес до проблеми вивчення психологічних особливостей людини в контексті брехливості. Важливість цієї проблеми очевидна: різні прояви брехні, обману, неправди (маніпуляції, шахрайство) постійно виявляються в ситуаціях міжособистісного спілкування, у соціальних і міжгрупових стосунках. У зв'язку з цим доцільно провести психологічний аналіз брехливості й рефлексивних проявів особистості в корисливих злочинців-рецидивістів, які в кримінальній діяльності неодноразово вдавалися до брехні (обману) з метою отримання матеріальної винагороди та задоволення власних корисливих мотивів. Ці питання в царині науки майже не досліджені, що зумовлює актуальність проведеного дослідження. 
Аналіз останніх досліджень і публікацій. Різноманітність теоретичних робіт з окресленої нами проблематики дає нам змогу детально проаналізувати рефлексивні прояви й аспекти брехливості особистості.

$€$. Заїка та О. Зімовін наголошують на тому, що варто розрізняти рефлексію та рефлексивність, оскільки рефлексія орієнтована на предмет, а рефлексивність - загальнолюдська здатність, яка характеризується континуальністю, дискретністю, парціальністю. Автори доходять висновку: «Якщо рефлексія - процес самопізнання, то рефлексивність - сама можливість існування цього процесу, здатність системи спрямовувати власну активність на саму себе» [1, с.92].

Заслуговують на особливу увагу при вивчення рефлексії праці А. Буземана, А. Россохіна, А. Карпова, В. Лепського, В. Лефевр, Г. Андрєєвої, О. Матюшкіна, В. Знакова, С. Степанова, Д. Леонтьєва, В. Петровського. Сучасні дослідники приділяють вивченню рефлексії не меншу увагу.

Так, Г. Ожиганова провела детальний психологічний аналіз робіт з вивчення рефлексії. Авторка показала, що це поняття в доробку містить різноманітні змістові наповнення і трактування, але нею виявлено три модуси рефлексії (процес, властивість і стан). Дослідниця вважає, що ці три напрями «дають змогу чітко визначити напрями психологічного дослідження цього феномена й розмежувати поняття «рефлексія» (процес) і «рефлексивність» (властивість, якість)» [7, с. 59].

Цікавим є огляд сучасної наукової дискусії про конструкт біографічної рефлексії М. Клементьєвої. У роботі дослідниця запропонувала оригінальну концепцію біографічної рефлексії, яку вона визначає як ресурс розвитку особистості дорослої людини. Авторка пропонує власне розуміння цього поняття: «Біографічна рефлексія як вид рефлексії проявляється в критичному аналізі життєвого шляху й, володіючи самостійним статусом психічного явища, не може бути зведена лише до методу дослідження особистості» [3, с. 60].

Аналіз ролі різних видів рефлексії в системі формування позитивних і негативних компонентів суб'єктивного благополуччя проведений Л. Карапетян. Так, дослідницею визначено, що системний рефлексивний процес сприяє підтримці рівноваги в системі емоційних та особистісних позитивних компонентів суб'єктивного благополуччя. «Рівень розвитку рефлексивних процесів відіграє величезну роль у підтриманні рівноваги в динамічній системі емоційно-особистісного благополуччя», зазначає Лариса Карапетян [2, с. 413].

Особливо ці напрацювання є вельми цікавимипрививченніпсихологічнихособливостей корисливих злочинців-рецидивістів у контек- сті їх брехливості. Як правило, у криміналістиці питання, що стосуються виявлення та діагностики брехні, розглядаються здебільшого в рамках загальної тактики проведення допиту.

$€$. Центров і К. Подвойський займалися вивченням криміналістичної діагностики брехливості. Автори вважають, що в умовах сьогоденняєвсіпередумовидляствореннясамостійного комплексного навчання криміналістичної діагностики брехні. «Ця теорія здатна узагальнити розрізнені дані, накопичені в цій сфері психологією, психофізіологією, а також криміналістичною практикою, і на основі цього розробити загальні рекомендації щодо виявлення брехні в ході розслідування злочинів», - резюмують Є. Центров та К. Подвойський [10, с.67].

Ми погоджуємося з думкою колег, оскільки також уважаємо, що вивчення й урахування особливостей формування брехні, її відмінностей на психофізіологічному рівні дасть змогу правоохоронцям, які займаються слідчими діями, розпізнати брехню, відрізнити її від подібних психологічних чинників у корисливих злочинців, які вже неодноразово відбували покарання.

I. Топоркова в роботі досить детально окреслює проблему брехливості особистості з точки зору криміналістики. Дослідниця вважає, що криміналістів цікавить обман як спосіб здійснення злочину [8, с. 199].

Робіт, присвячених вивченню психологічних особливостей і рис особи злочинця, чимало представлено в науковому просторі. О. Клименко при дослідженні особистісний рис злочинців, які вчинили шахрайства у сфері надання туристичних послуг, виділила низку ознак для цієї кримінальної спільноти. Дослідниця вважає, що ця категорія злочинців має достатньо розвинуту уяву й уміння переконувати людей. «До особистих якостей належать хитрість, брехливість, уміння викликати інтерес до себе, знання способів фальсифікації документів», - пише О. Клименко [4, с. 277].

Постановка завдання. Мета статті полягає в емпіричному дослідженні взаємозв'язків брехливості з диференційними типами рефлексії в корисливих злочинців-рецидивістів. Згідно з поставленою метою, визначені такі завдання: 1. Проаналізувати теоретичні аспекти поняття рефлекії та брехливості в працях вітчизняних учених. 2. Визначити взаємозв'язки брехливості з диференційними типами рефлексивності в корисливих злочинців-рецидивістів.

Виклад основного матеріалу дослідження. Згідно з А. Дік, існує безліч передумов, від функціонування сім'ї й до соціальних структур, вплив яких протягом усього життя людини сприяє формуванню особистісних властивостей, зумовлюють використання брехні й маніпуляцій при вирішенні життєво важливих проблем [6, с. 170]. 
Як зазначає І. Холодков, актуальним є вирішення питання, як співвідноситься схильність до брехні людини й рівень його рефлексії щодо ситуаційної адекватності поведінки, що й визначило мету цього дослідження. Дослідник вивчав оцінку схильності до брехні в контексті особливостей самомоніторингу. У результаті дослідження виявлено, що здатність керувати своєю поведінкою, емоційним виразом у ситуації прямо пов'язана з прагненням привернути увагу до себе, з потребою отримання позитивної оцінки, заохочення, підтримки тощо, які досягаються за допомогою брехні й обману [9, с. 159].

Відповідно до висунутих завдань, нами проведено емпіричне дослідження взаємозв'язків брехливості з диференційними типами рефлексивності в корисливих злочинців-рецидивістів. Вибірку становили 53 засуджені, які позбавлені волі за злочини, передбачені Карним кодексом України (шахрайство, вимагання, розбій, грабіж, крадіжка). Виділення груп дослідження здійснювалося за допомогою процедури кластерного аналізу за шкалами методики «Брехливість» І. Церковної. Було утворено дві групи досліджуваних, до яких корисливі злочинці-рецидивісти були включені на ґрунті результатів кластерного аналізу за принципом «ближніх сусідів». У першу групу увійшло 22 особи, до другої групи - 31 особа.

Нами використано опитувальник «Диференційний тип рефлексії» Д. Леонтьєва. Тест містить 30 тверджень, які обраховуються за 4-бальною шкалою Ліккерта. Пункти об'єднуються в три загальні шкали. Диференційний підхід до рефлексивності базується на виділенні однієї продуктивної - системній рефлексії - і двох непродуктивних рефлексій: квазірефлексія й інтроспекція. Системна рефлексія дає змогу поглянути на себе зі сторони та пов'язана із самодистанціюванням. Квазірефлексія направлена на об'єкт, який не містить значимої життєвої події. Інтроспекція відображає процес зосередження на власних переживаннях [5].

«Структурно-функціональний опитувальник брехливості» І. Церковної, який містить 86 стверджень і 12 шкал: динамічна ергічність; динамічна аергічність; емоційна стенічність; емоційна астенічність; регуляторна інтернальність; регуляторна екстернальність; мотиваційна соціоцентричність; мотиваційна егоцентричність; когнітивна осмисленість; когнітивна усвідомленість; результативна предметність; результативність суб'єктна [11].

Для математико-статистичної обробки використано t-критерій Стьюдента для незалежних груп і коефіцієнт рангової кореляції Спірмена. Результати, отримані в дослідженні, наведено в таблицях 1-3.
Показники диференційних типів рефлексії в корисливих злочинців-рецидивістів наведено в таблиці 1.

За шкалою «Системна рефлексія» показник у першій групі корисливих злочинців-рецидивістів становив 82,17 $\pm 2,80$, у другій групі

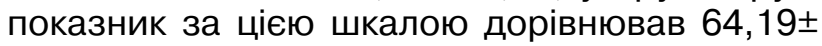
2,72 . Математико-статистичний аналіз дав змогу встановити в першій групі вірогідно більший показник при $t=4,63, p \leq 0,01$.

Отже, для першої групи корисливих злочинців-рецидивістів більш притаманною $є$ здатність до системної рефлексії, тобто до самодистанціювання й погляду на себе з боку, що дає змогу охопити водночас полюс суб'єкта й полюс об'єкта.

За шкалою «Квазірефлексія» показник у першій групі становив 96,94ะ3,21, у другій групі показник за цією шкалою дорівнював $58,77 \pm 3,35$. Математико-статистичний аналіз допоміг установити в першій групі вірогідно більший показник при $\mathrm{t}=8,19, \mathrm{p} \leq 0,001$.

Виявлені відмінності свідчать про те, що корисливим злочинцям першої групи більш притаманною $€$ спрямованість рефлексії на об'єкти, які не мають відношення до актуальної життєвої ситуації й пов'язані з відривом від актуальної ситуації буття у світі.

За шкалою «Інтроспекція» показник у першій групі становив $104,53 \pm 3,80$, у другій групі показник за цією шкалою дорівнював 62,02 3,44 . Математико-статистичний аналіз дав змогу встановити в першій групі корисливих злочинців-рецидивістів вірогідно більший показник при $\mathrm{t}=8,30, \mathrm{p} \leq 0,001$.

Виявлені відмінності свідчать про те, що злочинці-рецидивісти корисливого типу, які ввійшли до першої групи, характеризуються більшою вираженістю схильності до інтроспекції, тобто вони більш схильні до зосередженості на власному стані, на власних переживаннях.

Взаємозв'язки структурно-функціональних складників брехливості й диференційних типів рефлексії в першій групі корисливих злочинців-рецидивістів наведено в таблиці 2.

У першій групі корисливих злочинців-рецидивістів між диференційним типом рефлексії «Системна рефлексія» встановлені значущі додатні взаємозв'язки зі структурно-функціональними складниками брехливості «емоційна стенічність» $(r=0,621)$, «мотиваційна соціоцентричність» $(r=0,519)$, а також від'ємний значущий взаємозв'язок зі структурно-функціональним складником брехливості «динамічна аергічність» $(r=-0,684)$.

Зміст виявлених взаємозв'язків свідчить про те, що з посиленням здатності до системної рефлексії, тобто до самодистанціювання й погляду на себе з боку, що дає змогу охопити водночас полюс суб'єкта та полюс об'єкта, в цій групі відбувається таке: 
- збільшується схильність до брехливості, яка демонструється в більшому прояві позитивних емоцій: радості, задоволення («емоційна стенічність»);

- зростає схильність до брехливості, яка демонструється при підкресленні власної значущості в рішенні суспільних питань, конфліктах («мотиваційна соціоцентричність»);

- меншої вираженості набувають прояви брехливості, які проявляються в запереченні самостійності, активності, страху викриття («динамічна аергічність»).

у цій групі між диференційним типом рефлексії «Квазірефлексія» встановлені зна- чущі додатні взаємозв'язки зі структурнофункціональними складовими брехливості «динамічна аергічність» $(r=0,529)$, «регуляторна інтернальність» $(r=0,519)$, «Мотиваційна соціоцентричність» $(r=0,539)$, а також від'ємний значущий взаємозв'язок зі структурно-функціональною складовою брехливості «результативність суб'єктна» $(r=-0,560)$.

Отже, у першій групі корисливих злочинців-рецидивістів з посиленням спрямованості рефлексії на об'єкти, які не мають відношення до актуальної життєвої ситуації й пов'язані з відривом від актуальної ситуації буття у світі, набувають більшої вираженості:

Показники диференційних типів рефлексії в корисливих злочинців-рецидивістів

Таблиця 1 $(\mathbf{M} \pm \mathbf{m})$

\begin{tabular}{|l|l|l|l|l|}
\hline Шкали & Група 1 & Група 2 & $\mathrm{t}$ & $\mathrm{p}$ \\
\hline Системна рефлексія & $82,17 \pm 2,80$ & $64,19 \pm 2,72$ & 4,63 & 0,01 \\
\hline Квазірефлексія & $96,94 \pm 3,21$ & $58,77 \pm 3,35$ & 8,19 & 0,001 \\
\hline Інтроспекція & $104,53 \pm 3,80$ & $62,02 \pm 3,44$ & 8,30 & 0,001 \\
\hline
\end{tabular}

Таблиця 2

Взаємозв'язки структурно-функціональних складників брехливості й диференційних типів рефлексії в першій групі корисливих злочинців-рецидивістів ( $r$ )

\begin{tabular}{|l|l|l|l|}
\hline Шкали & Системна рефлексія & Квазірефлексія & Інтроспекція \\
\hline Динамічна ергічність & $-0,116$ & 0,019 & $0,506^{\star}$ \\
\hline Динамічна аергічність & $-0,684^{\star}$ & $0,529^{\star}$ & $-0,616^{\star}$ \\
\hline Емоційна стенічність & $0,621^{\star}$ & $-0,207$ & -0.211 \\
\hline Емоційна астенічність & $-0,275$ & 0,208 & 0,232 \\
\hline Регуляторна інтернальність & 0,227 & $0,519^{\star}$ & 0,260 \\
\hline Регуляторна екстернальність & $-0,244$ & 0,247 & 0,213 \\
\hline Мотиваційна соціоцентричність & $0,519^{\star}$ & $0,539^{\star}$ & 0,174 \\
\hline Мотиваційна егоцентричність & $-0,209$ & $-0,252$ & 0,289 \\
\hline Когнітивна осмисленість & 0,020 & $-0,259$ & 0,171 \\
\hline Когнітивна усвідомленість & $-0,282$ & 0,161 & 0,110 \\
\hline Результативна предметність & $-0,117$ & $-0,219$ & 0,216 \\
\hline Результативність суб'єктна & $-0,230$ & $-0,560^{\star}$ & 0,221 \\
\hline
\end{tabular}

Таблиця 3

Взаємозв'язки структурно-функціональних складників брехливості й диференційних типів рефлексії в другій групі корисливих злочинців-рецидивістів (r)

\begin{tabular}{|l|l|l|l|}
\hline Шкали & Системна рефлексія & Квазірефлексія & Інтроспекція \\
\hline Динамічна ергічність & $-0,249$ & $-0,274$ & $0,520^{\star}$ \\
\hline Динамічна аергічність & $-0,186$ & $0,501^{\star}$ & 0,263 \\
\hline Емоційна стенічність & $0,566^{\star}$ & $0,574^{\star}$ & 0,289 \\
\hline Емоційна астенічність & $-0,604^{\star}$ & $-0,506^{\star}$ & 0,264 \\
\hline Регуляторна інтернальність & 0,280 & $0,667^{*}$ & $-0,230$ \\
\hline Регуляторна екстернальність & 0,209 & 0,171 & 0,198 \\
\hline Мотиваційна соціоцентричність & $0,530^{\star}$ & $-0,606^{\star}$ & $-0,187$ \\
\hline Мотиваційна егоцентричність & 0,162 & 0,222 & $0,572^{\star}$ \\
\hline Когнітивна осмисленість & $-0,543^{\star}$ & 0,260 & 0,257 \\
\hline Когнітивна усвідомленість & $-0,195$ & 0,259 & $0,527^{\star}$ \\
\hline Результативна предметність & 0,244 & $0,625^{\star}$ & $-0,117$ \\
\hline Результативність суб'єктна & $-0,059$ & 0,171 & 0,266 \\
\hline
\end{tabular}


- брехливість, яка проявляється в запереченні самостійності, активності, страху викриття («динамічна аергічність»);

- брехливість, яка проявляється в самокритиці, серйозності власних рішень, у брехливій демонстрації незалежності від інших, власної значущості («регуляторна інтернальність»);

- брехливість, яка демонструється при підкресленні власної значущості у вирішенні суспільних питань, конфліктів («мотиваційна соціоцентричність»).

Крім того, зі зростанням схильності до квазірефлексії в цій групі меншої вираженості набуває брехливість, яка проявляється при запереченні власної спрямованості на особистісно-значущий результат, при нездатності до самореалізації («результативність суб'єктна»).

У першій групі між диференційним типом рефлексії «Інтроспекція» встановлено додатний значущий взаємозв'язок зі структурно-функціональною складовою брехливості «динамічна ергічність» $(r=0,506)$ та від'ємний значущий взаємозв'язок зі структурно-функціональним складником брехливості «динамічна аергічність» $(\mathrm{r}=-0,616)$.

Отже, у цій групі зі зростанням схильності до інтроспекції, тобто схильності до зосередженості на власному стані, власних переживаннях:

- більш вираженою стає схильність до брехливості, яка демонструється в активності, оперативності, самостійності, прагненні бути кращим за інших («динамічна ергічність»);

- набуває меншої вираженості брехливість, яка проявляється в запереченні самостійності, активності, страху викриття («динамічна аергічність»).

Взаємозв'язки структурно-функціональних складників брехливості й диференційних типів рефлексії в другій групі корисливих злочинців-рецидивістів наведено в таблиці 3.

У другій групі корисливих злочинців-рецидивістів між диференційним типом рефлексії «Системна рефлексія» встановлено значущі додатні взаємозв'язки зі структурно-функціональними складниками брехливості «емоційна стенічність» $(r=0,566)$, «мотиваційна соціоцентричність» $(r=0,530)$, а також від'ємний значущий взаємозв'язок зі структурно-функціональним складником брехливості «емоційна астенічність» $(r=-0,604)$, «когнітивна осмисленість» $(r=-0,543)$.

Зміст виявлених взаємозв'язків свідчить про те, що з посиленням здатності до системної рефлексії, тобто до самодистанціювання й погляду на себе з боку, що дає змогу охопити водночас полюс суб'єкта й полюс об'єкта в цій групі, відбувається таке:

- збільшується схильність до брехливості, яка демонструється в більшому прояві позитивних емоцій: радості, задоволення («емоційна стенічність»);
- зростає схильність до брехливості, яка демонструється при підкресленні власної значущості в рішенні суспільних питань, конфліктів («мотиваційна соціоцентричність»);

- меншої вираженості набуває схильність до брехливості, яка проявляється в більшому прояві негативних емоцій: смуток, печаль («емоційна астенічність»);

- меншої вираженості набуває схильність до брехливості, яка проявляється у зв'язках з розумінням сутності предметів і явищ через процес мислення («когнітивна осмисленість»).

у цій групі між диференційним типом рефлексії «Квазірефлексія» встановлено значущі додатні взаємозв'язки зі структурно-функціональними складниками брехливості «динамічна аергічність» $(r=0,501)$, «емоційна стенічність» $(r=0,574)$, «регуляторна інтернальність» $(r=0,667), \quad$ «результативна предметність» $(r=0,625)$, а також від'ємний значущий взаємозв'язок зі структурно-функціональним складником брехливості «емоційна астенічність» ( $r=-0,506)$, «мотиваційна соціоцентричність» ( $r=-0,606)$.

Отже, у другій групі корисливих злочинців-рецидивістів із посиленням спрямованості рефлексії на об'єкти, які не мають відношення до актуальної життєвої ситуації й пов'язані з відривом від актуальної ситуації буття у світі, набувають більшої вираженості:

- брехливість, яка проявляється в запереченні самостійності, активності, страхувикриття («динамічна аергічність»);

- брехливість, яка проявляється в самокритиці, серйозності власних рішень, у брехливій демонстрації незалежності від інших, власної значущості («регуляторна інтернальність»);

брехливість, яка демонструється при вчинках, висловлюваннях («емоційна стенічність»);

- брехливість проявляється при демонстрації спрямованості на соціально-значимий результат, при брехливому прагненні до самореалізації, бажанні досягти позитивних відносин з оточуючими («результативність предметна»).

Крім того, зі зростанням схильності до квазірефлексії в цій групі меншої вираженості набувають:

- брехливість, яка проявляється пасивністю, бездіяльністю («емоційна астенічність»);

- брехливість, яка проявляється у формуванні особистості («мотиваційна соціоцентричність»).

У другій групі корисливих злочинців-рецидивістів між диференційним типом рефлексії «інтроспекція» встановлено додатній значущий взаємозв'язок зі структурно-функціональним складником брехливості «динамічна ергічність» $(r=0,520)$, «мотиваційна егоцентричність» $(r=0,572)$, «когнітивна усвідомленість» $(r=0,527)$. 
Отже, у цій групі зі зростанням схильності до інтроспекції, тобто схильності до зосередженості на власному стані, власних переживаннях:

- більш вираженою стає схильність до брехливості, яка проявляється в активності, оперативності, самостійності, прагненні бути кращим за інших («динамічна ергічність»);

- більш вираженою стає схильність до брехливості, яка демонструється в захопленості будь-чим заради демонстрації своїх успіхів («мотиваційна егоцентричність»).

- більш вираженою стає схильність до брехливості, яка проявляється в спостереженні за поточнимипереживаннями, тобтостан, уякому суб'єкт фокусується на переживанні справжнього моменту («когнітивна усвідомленість»).

Висновки 3 проведеного дослідження. Результати проведеного емпіричного дослідження дали змогу зробити низку висновків. Отже, у першій групі корисливих злочинців-рецидивістів шкала «Системна рефлексія» прямо корелює на значущому рівні зі структурно-функціональними складниками брехливості «Емоційна стенічність» і «Мотиваційна соціоцентричність», а також зворотно - зі структурно-функціональним складником брехливості «Динамічна аергічність». Шкала «Квазірефлексія» в цій групі виявляє значущі прямі кореляції зі структурно-функціональними складниками брехливості «Динамічна аергічність», «Регуляторна інтернальність» і «Мотиваційна соціоцентричність» і зворотні значущі кореляції зі структурно-функціональним складником брехливості «Результативність суб'єктна». Шкала «нтроспекція» в першій групі прямо корелює зі структурно-функціональним складником брехливості «Динамічна ергічність» і зворотно - зі структурно-функціональним складником брехливості «Динамічна аергічність».

У другій групі корисливих злочинців-рецидивістів шкала «Системна рефлексія» прямо корелює на значущому рівні зі структурно-функціональними складниками брехливості «Емоційна стенічність» і «Мотиваційна соціоцентричність», а також зворотно - зі структурно-функціональним складником брехливості «Емоційна астенічність», «Когнітивна осмисленість». Шкала «Квазірефлексія» в цій групі виявляє значущі прямі кореляції зі структурно-функціональними складниками брехливості «Динамічна аергічність», «Результативна предметність» і «Регуляторна інтернальність» і зворотні значущі кореляції зі структурно-функціональним складником брехливості «Емоційна астенічність», «Мотиваційна соціоцентричність». Шкала «Інтроспекція» в другій групі прямо корелює зі структурно-функціональним складником брехливості «Динамічна ергічність», «Мотиваційна егоцентричність», «Когнітивна усвідомленість».

Отже, установлено, що диференційні типи рефлексії виявляють відмінну структуру взаємозв'язків зі структурно-функціональними складниками брехливості у двох групах корисливих злочинців-рецидивістів. Варто підкреслити, що означені чинники брехливості характеризуються різним внеском у її функціонування.

Феномен брехливості в корисливих злочинців-рецидивістів вимагає більш детального вивчення цього аспекту означеної проблеми в працях зарубіжних учених та окреслює перспективні вектори подальших досліджень.

\section{ЛІТЕРАТУРА:}

1. Заїка $€$., Зімовін О. Рефрлексивність особистості як предмет психологічного пізнання. Психологія $i$ суспільство. 2014. №. 2. С. 90-97.

2. Карапетян Л.В. Рефлексивные процессы в структуре эмоционально-личностного благополучия. Ученые записки университета Лесгафта. 2020. № 1 (179). C. 412-414.

3. Клементьева М.В. Теоретико-методологические аспекты психологического исследования биографической рефлексии личности. СПЖ. 2020. № 77. с. 44-67.

4. Клименко О.А. Деякі особливості особи злочинця, що вчиняє шахрайства у сорері туристичних послуг. Протидія злочинності: теорія та практика : матеріали VII Всеукраїнської науково-практичної конфреренції (19 жовтня 2016 року). Київ : Національна академія прокуратури України, 2016. С. 276-277.

5. Леонтьев Д.А., Осин Е.Н. Ресллексия «хорошая» и «дурная»: от объяснительной модели к диффференциальной диагностике. Психология. Журнал Высшей школы экономики. 2014. Т. 11. № 4. С. 110-135.

6. Муртазин И.С. К вопросу об индивидуально-психологических особенностях склонной к лжи личности. Инновационная наука: прошлое, настоящее, будущее. 2016. С. 170-172.

7. Ожиганова Г.В. Рефлексия, рефлексивность и высшие рефлексивные способности: подходы к исследованию. Вестник Костромского государственного университета. Серия «Педагогика. Психология. Социокинетика». 2018. № 4. С. 56-60.

8. Топоркова І.В. Взаємозв'язки структурно-фрункціональних складових брехливості з особистісними рисами у жінок-злочинниць та жінок з умовно-нормативною поведінкою. Психологічний часопис. 2018. № 4 (6). С. 198-212.

9. Холодков И. Склонность ко лжи в контексте особенностей самомониторинга. Вестник психологии и педагогики Алтайского государственного университета. 2017. № 2. С. 154-162.

10. Центров Е.Е., Подвойский К.В. Криминалистическая диагностика лжи: теоретические основы. Вестник Московского университета. Серия 11 «Право». 2016. № 4. С. 59-67.

11. Церковная И.А. Многомернофуункциональное исследование лживости как индивидуально-психологической особенности личности : дисс. ... канд. психол. наук :19.00.01. Екатеринбург, 2006. 186 с. 